\title{
A Study of Consumer Preferences and Market Potential for Poultry Products in Kumi District of Uganda
}

\author{
Iisa Augustine and Ruchira Shukla*
}

\author{
ASPEE Agribusiness Management Institute, Navsari Agricultural University, \\ Navsari, Gujarat, India \\ *Corresponding author
}

\author{
A B S T R A C T
}

\begin{tabular}{|l|}
\hline Ke y w o r d s \\
$\begin{array}{l}\text { Poultry, Market } \\
\text { potential, Consumer } \\
\text { preference. }\end{array}$ \\
\hline Article Info \\
$\begin{array}{l}\text { Accepted: } \\
\text { 23 September } 2017 \\
\text { Available Online: } \\
\text { 10 October } 2017\end{array}$ \\
\hline
\end{tabular}

A study was conducted to understand consumer preferences and market potential for the backyard poultry rearing system in Kumi district of Uganda. This study revealed that $70 \%$ of the consumers included poultry products in their menus often and $10 \%$ included daily. Poultry traders in Kumi district dealt mainly with indigenous chicken breeds as their customers preferred them to others due to taste and less chemical residues.70\% of individual consumers considered taste as first priority when choosing chicken.80\% of individual consumers preferred backyard chickens to other chicken or poultry breeds. $57.5 \%$ of the consumers preferred consuming chicken once in a week, $32.5 \%$ preferred consuming it fortnightly and only $10 \%$ preferred consuming it every day. $100 \%$ of the consumers preferred eggs from backyard chickens. However, due to scarcity of the backyard chicken eggs, $75 \%$ of the consumers bought exotic layers eggs. A market potential within Kumi District alone for poultry was computed to be 3,290,588 birds per year, for which $20 \%$ is for broilers (i.e. 658,118 birds) and the rest being for backyard poultry, (i.e. $2,632,470$ birds).

\section{Introduction}

The poultry industry in Uganda is composed of 43.4 million birds, and it has been growing at a rate of about $3 \%$ per annum (UBOS, 2013). A part from chickens, other species of poultry kept mainly in rural areas included turkeys, ducks, guinea fowls, geese and pigeons. The poultry numbers in Uganda was estimated to consist of mainly chickens. Over 90\% of Ugandan chickens were indigenous stock reared under the Backyard system (Olaboro 1990), producing an average of 50 eggs per hen per year. The other $10 \%$ consisted of improved exotic commercial layers and broilers kept under the intensive system of production mainly in urban areas. About half of the households in Uganda $(50.1 \%)$ owned chicken as of 2008 (MAAIF/UBOS, 2009). The estimated number of households owning chicken in Uganda was 3.2 million. Almost all the chicken-owning households (99.2\%) owned indigenous chicken. The national chicken flock for Uganda was estimated to be 37.4 million as of 2008. Regionally, the Eastern Region has the highest number of chicken estimated to be 10.7 million (28.6\%), while the Western Region has the least number of chicken estimated to be 7.2 million (19.3\%). 
Districts of Wakiso (2.8 million), Bugiri (0.9 million), Lira (1.1 million) and Masindi (1.0 million) had the highest number of chicken in Central, Eastern, Northern and Western regions respectively.

Backyard poultry, synonymously know as indigenous/local poultry, etc., and particularly backyard/indigenous/local chickens, remain an easily available and cheap source of animal proteins for the majority of people as it is widely kept by the masses. However, the backyard poultry is mainly kept in small numbers and are not properly managed by the farmers. The poultry is left to scavenge for own food.

Meat and eggs from the backyard poultry are generally preferred to those from commercial birds because of their taste, leanness and suitability for special dishes (Kryger et.al.2010). They are therefore sold at premium market prices. Development of the backyard poultry sector plays an important role in increasing overall production of the eggs and poultry meat, providing income and employment to a large number of people in rural areas.

There is a need to study the available potential for backyard chickens that will maximize returns for farmers through commercialisation of backyard chicken farming in Kumi district. Keeping this in view, the present study was conducted to understand consumer preferences and available market potential for Backyard poultry products in Kumi district.

\section{Materials and Methods}

Primary data was collected from 10 chicken traders, 20 restaurants/hotels, 40 individual consumers and 10 supermarkets in Kumi district of Uganda.In addition to Kumi district, the districts of Mbale and Soroti were purposively selected for survey of restaurants/hotels/supermarkets and individual consumers because these districts consume most of the chickens from Kumi district. Convenience sampling was adopted for the selection of restaurants/hotels/supermarkets and consumers. Discussions were held with poultry traders at Odelo cattle/livestock market in Kumi district as well as poultry traders in Kumi Bus Park/Kumi Town Council.

Primary data was collected using structured personal interviews, using interview schedules. A discussion with traders was carried out using interview schedule. The collected raw data was edited, coded and classified accordingly. The quantitative raw data was analysed using excel and narrative analysis done for qualitative information.Descriptive statistics was used to obtain frequencies and percentages. Cross tabulations were done in some cases in order to understand relationships between some variables.

\section{Results and Discussion}

\section{Socio Economic Characteristics of Individual Consumers}

Table 1 below shows the number of individual consumers (40) who were interviewed, according to gender, age, marital status, religion, level of formal education and incomes

Of the 40 respondents that were interviewed, $60 \%$ were females and $40 \%$ were males. $50 \%$ of the respondents were not married, $42.5 \%$ were married, and the rest were either widowed or cohabiting. $40 \%$ of the respondents were of the age group of 18 to 25 years, $35 \%$ were 26 to 33 years and $10 \%$ were 34 to 41 years. There were no respondents 
who were less than 18 years. This could be because most of those in this age bracket are still dependents. Only $15 \%$ of the respondents were more than 41 years of age. This could be because persons of this age group are more concern about their health and therefore prefer to limit consumption of protein rich products like poultry products.

$35 \%$ of the respondents were Muslims and the rest were Christians of three different denominations. These two religions have no restrictions against consumption of poultry products, and just like Christmas festivals for Christians, chicken is a common meal for Muslims during their annual Muslim festivals like Eid Al-Fitr and Eid Al-Adha. It is also taken as one of the best meals prepared for visitors.

None of the respondents was illiterate. $67.5 \%$ of the respondents had attained tertiary education with majority having graduate qualifications. $20 \%$ had stopped at secondary, and $12.5 \%$ ended in primary level. Educated people are always mindful of balancing their diets which must include rich protein sources like poultry products.

$37.5 \%$ of the respondents had income levels of UShs. 500,000 to $1,000,000.32 .5 \%$ had $1,000,001$ to $2,000,000 ; 20 \%$ had $2,000,001$ and above, while only $10 \%$ had below UShs. 500,000 .

\section{Frequency at which poultry products were included in consumers' daily menus}

As per the Table 2, $70 \%$ of the respondents included poultry products in their menus often and $10 \%$ include daily. The high frequencies at which the poultry products are included in individual consumers' daily menus, i.e. $80 \%$ always and often, can be attributed to the larger proportions of females, a Christian and Muslim dominated society, higher education levels, young age groups and income levels of this study`s respondents (Table 1).

For instance, a cross tabulation of gender verses the frequency at which poultry products are included in individual consumers' daily menus revealed that the actual consumption frequency of poultry products is higher among females than males, (Table 3).

In view of this revelation (Table 3), Kumi district stands an opportunity of exploiting the available poultry market by commercialising backyard poultry production. Moreover, there are more females than males not only in Kumi district, but in Uganda as a country, as cited in the provisional results of Uganda's 2014 National Population Census (UBOS, 2014).

\section{Preferences for poultry by individual consumers}

$70 \%$ of the individual consumers often included poultry products in their daily menus and $57.5 \%$ of the consumers secured their supplies of the products from traders (Table 4).

In regard to individual consumer's preference for poultry, taste is first priority considered $(70 \%) .80 \%$ of the consumers preferred backyard chickens. $57.5 \%$ of the consumers preferred consuming chicken once in a week, $32.5 \%$ preferred consuming it fortnightly and only $10 \%$ preferred consuming it every day. $40 \%$ prefer chicken carcass weight of 1.0 to $1.5 \mathrm{kgs}, 35 \%$ prefer 1.6 to $2.0 \mathrm{kgs}$ and $25 \%$ prefer 2.1 to $2.5 \mathrm{kgs}$.

\section{Period of highest demand by individual consumers}

All individual consumers indicated that their highest demand for poultry is from October to December. This is because of festive seasons 
that take place in these months, including Christmas, New Year Celebrations and Muslim festivals. This is also a season when most students/children are at home for holidays from school, and this raises household food consumption levels. Most students prefer to eat better food when they are at home for holidays, and chicken is considered such foods suitable for holiday makers.

Prices paid by individual consumers for live chickens during peak and lean seasons of supplies

From Table 5, it is observed that individual consumers tended to pay the same price for broiler chickens during both lean and peak seasons of broiler supplies. However they were willing to pay UShs. 5,000 to 10,000 for each broiler chicken.

From Table 6, it was observed that individual consumers tended to pay more for a backyard chicken during lean seasons than during peak seasons of their supplies. However they were willing to pay UShs. 11,000 to 15,000 for each backyard chicken, indicating price parity with other chickens.

\section{Preferences for chicken eggs by individual} consumers

In regard to individual consumer's preference for eggs, $100 \%$ of the consumers preferred eggs from backyard chickens, and they were willing to buy a tray at UShs. 11,000 to 15,000. However, due to scarcity of the backyard chicken eggs, $75 \%$ of the consumers bought exotic layer eggs, and one reason for this was availability (Table 7).

\section{Characteristics of restaurants/hotels/ supermarkets}

$55 \%$ of the restaurants/Hotels surveyed in Kumi district were 6 to 10 years old in business, $25 \%$ were 11 to 15 years and $20 \%$ were 1 to 5 years (Figure 1). They were located in urban and semi-urban areas. Supermarkets were owned and operated by Indians. No supermarket provided any information as they were not dealing in poultry products.

The production system vs. poultry trade and consumption

\section{Poultry traders}

Despite the dominance of the free range system amongst the farmers, discussions with poultry traders confirmed that the poultry system makes it very difficult for them to secure reliable supplies of their required poultry numbers. Weekly procurements of chickens from farmers by each trader range from 40 to 50 birds, and daily sales by the trader to consumers range from 6 to 10 birds. The traders prefer all sizes of chickens as long as they are of edible age, but they have to move around the villages looking for them, or wait competitively for the farmers to deliver them to the livestock market. Backyard chickens are preferred by the traders to other breeds of poultry.

The traders said the peak seasons for supply of chickens from farmers are from September to February. Shortages are experienced during the wet seasons of April to August as many farmers get engaged in crop farming.

There is no significant difference in the prices that traders offer farmers for their poultry between the peak and the lean seasons. They buy from the farmers at a price range of UShs. 7,000 to 11,000 .

However, the final consumer usually pays more for a chicken bought from a trader during festive seasons from October to December, simply because demand increases during these months. 
Table.1 Socio economic characteristics of individual consumers interviewed. $n=40$

\begin{tabular}{|c|c|c|}
\hline Variable & Frequency & Percentage \\
\hline \multicolumn{3}{|c|}{ Gender } \\
\hline Males & 16 & $40.0 \%$ \\
\hline Females & 24 & $60.0 \%$ \\
\hline \multicolumn{3}{|c|}{ Marital Status } \\
\hline Married & 17 & $42.5 \%$ \\
\hline Widowed & 1 & $2.5 \%$ \\
\hline Single & 20 & $50.0 \%$ \\
\hline Cohabiting & 2 & $5.0 \%$ \\
\hline Divorced & 0 & $0.0 \%$ \\
\hline \multicolumn{3}{|c|}{ Age } \\
\hline$<18$ & 0 & $0.0 \%$ \\
\hline $18-25$ & 16 & $40.0 \%$ \\
\hline $26-33$ & 14 & $35.0 \%$ \\
\hline $34-41$ & 4 & $10.0 \%$ \\
\hline $42-49$ & 5 & $12.5 \%$ \\
\hline 50 and more & 1 & $2.5 \%$ \\
\hline \multicolumn{3}{|c|}{ Religion } \\
\hline Protestant & 12 & $30.0 \%$ \\
\hline Catholic & 12 & $30.0 \%$ \\
\hline Born Again & 2 & $5.0 \%$ \\
\hline Muslim & 14 & $35.0 \%$ \\
\hline \multicolumn{3}{|c|}{ Education Levels } \\
\hline Illiterate & 0 & $0.0 \%$ \\
\hline Primary & 5 & $12.5 \%$ \\
\hline Secondary & 8 & $20.0 \%$ \\
\hline Diploma & 6 & $15.0 \%$ \\
\hline Graduate & 21 & $52.5 \%$ \\
\hline \multicolumn{3}{|c|}{ Household Income } \\
\hline Below 500,000 & 4 & $10.0 \%$ \\
\hline $500,000-1,000,000$ & 15 & $37.5 \%$ \\
\hline $1,000,001-2,000,000$ & 13 & $32.5 \%$ \\
\hline $2,000,001 \&$ above & 8 & $20.0 \%$ \\
\hline
\end{tabular}


Table.2 Frequency at which poultry products were included in consumers' daily menus $n=40$

\begin{tabular}{|l|c|c|}
\hline \multicolumn{1}{|c|}{ Variable } & Frequency & Percentage \\
\hline Always (Daily) & 4 & $10.0 \%$ \\
\hline Often & 28 & $70.0 \%$ \\
\hline Occasionally & 8 & $20.0 \%$ \\
\hline Rarely & 0 & $0.0 \%$ \\
\hline Never & 0 & $0.0 \%$ \\
\hline
\end{tabular}

Table.3 Actual frequency of eating poultry products by Gender $M=16, F=24$

\begin{tabular}{|l|c|c|c|c|}
\hline & \multicolumn{2}{|c|}{ Males (M) } & \multicolumn{2}{c|}{ Females (F) } \\
\hline Variable & Numbers & $\%$ & Numbers & $\%$ \\
\hline Always (Daily) & 1 & $6.25 \%$ & 3 & $12.50 \%$ \\
\hline Often & 10 & $62.50 \%$ & 18 & $75.00 \%$ \\
\hline Occasionally & 5 & $31.25 \%$ & 3 & $12.50 \%$ \\
\hline Rarely & 0 & $0 \%$ & 0 & $0 \%$ \\
\hline Never & 0 & $0 \%$ & 0 & $0 \%$ \\
\hline Total & 16 & $100.00 \%$ & 24 & $100.00 \%$ \\
\hline
\end{tabular}

Table.4 Individual consumers' preferences for poultry $n=40$

\begin{tabular}{|l|c|c|}
\hline \multicolumn{1}{|c|}{ Variable } & Frequency & Percentage \\
\hline Frequency at which Poultry Products are included in Individual Consumers` daily menus \\
\hline Always & 4 & $10.0 \%$ \\
\hline Often & 28 & $70.0 \%$ \\
\hline Occasionally & 8 & $20.0 \%$ \\
\hline Rarely & 0 & $0.0 \%$ \\
\hline Never & 0 & $0.0 \%$ \\
\hline How individual Consumers secure their supplies of poultry products \\
\hline Tenders & 0 & $0.0 \%$ \\
\hline Buy from Town Market & 7 & $17.5 \%$ \\
\hline Buy from Village Market & 6 & $15.0 \%$ \\
\hline Vendors/Traders & 23 & $57.5 \%$ \\
\hline Direct from Farmers & 2 & $5.0 \%$ \\
\hline Other & 2 & $5.0 \%$ \\
\hline Preferred Chicken Qualities by Individual Consumers & \\
\hline Feather Colour & 0 & $0.0 \%$ \\
\hline
\end{tabular}




\begin{tabular}{|c|c|c|}
\hline Body Weight/makeup & 8 & $20.0 \%$ \\
\hline Taste & 28 & $70.0 \%$ \\
\hline Other & 4 & $10.0 \%$ \\
\hline \multicolumn{3}{|c|}{ Type of chicken preferred by individual consumers to buy } \\
\hline Backyard/Local & 32 & $80.0 \%$ \\
\hline Exotic Layers & 0 & $0.0 \%$ \\
\hline Exotic Broilers & 8 & $20.0 \%$ \\
\hline Hybrids & 0 & $0.0 \%$ \\
\hline Other & 0 & $0.0 \%$ \\
\hline \multicolumn{3}{|c|}{ Why the Preference for the chicken type bought by individual consumers } \\
\hline Tasty & 28 & $70.0 \%$ \\
\hline Soft & 8 & $20.0 \%$ \\
\hline Hard & 0 & $0.0 \%$ \\
\hline Healthy & 4 & $10.0 \%$ \\
\hline Referred by Medic & 0 & $0.0 \%$ \\
\hline Heavy weight & 0 & $0.0 \%$ \\
\hline Cheap & 0 & $0.0 \%$ \\
\hline Other & 0 & $0.0 \%$ \\
\hline \multicolumn{3}{|c|}{ Number of times an individual consumer prefers to eat chicken } \\
\hline Everyday & 4 & $10.0 \%$ \\
\hline Once a Week & 23 & $57.5 \%$ \\
\hline Fortnightly & 13 & $32.5 \%$ \\
\hline Once a month & 0 & $0.0 \%$ \\
\hline Occasionally & 0 & $0.0 \%$ \\
\hline Other & 0 & $0.0 \%$ \\
\hline \multicolumn{3}{|c|}{ Most Preferred weight of chicken by individual consumers } \\
\hline$<1$ & 0 & $0.0 \%$ \\
\hline $1-1.5$ & 16 & $40.0 \%$ \\
\hline $1.6-2.0$ & 14 & $35.0 \%$ \\
\hline $2.1-2.5$ & 10 & $25.0 \%$ \\
\hline $2.6-3.0$ & 0 & $0.0 \%$ \\
\hline$>3$ & 0 & $0.0 \%$ \\
\hline Other & 0 & $0.0 \%$ \\
\hline
\end{tabular}


Table.5 Price paid during peak and lean seasons, and the price a consumer is willing to pay for broiler chicken $n=8$

\begin{tabular}{|l|c|c|}
\hline \multicolumn{1}{|c|}{ Variable } & Frequency & Percentage \\
\hline \multicolumn{2}{|c|}{ Price paid by individual consumer during peak seasons of broiler chicken supplies } \\
\hline$<5,000$ & 0 & $0.0 \%$ \\
\hline $5,000-10,000$ & 4 & $50.0 \%$ \\
\hline $11,000-15,000$ & 4 & $50.0 \%$ \\
\hline$>15,000$ & 0 & $0.0 \%$ \\
\hline Price paid by individual consumer during lean seasons of broiler chicken supplies \\
\hline$<5,000$ & 0 & $0.0 \%$ \\
\hline $5,000-10,000$ & 4 & $50.0 \%$ \\
\hline $11,000-15,000$ & 4 & $50.0 \%$ \\
\hline$>15,000$ & 0 & $0.0 \%$ \\
\hline Price an individual consumer in willing to pay for a mature broiler chicken \\
\hline$<5,000$ & 0 & $0.0 \%$ \\
\hline $5,000-10,000$ & 8 & $100.0 \%$ \\
\hline $11,000-15,000$ & 0 & $0.0 \%$ \\
\hline$>15,000$ & 0 & $0.0 \%$ \\
\hline
\end{tabular}

Table.6 Price paid during peak and lean seasons, and the price a consumer is willing to pay for backyard chickens $n=32$

\begin{tabular}{|l|c|c|}
\hline \multicolumn{1}{|c|}{ Variable } & Frequency & Percentage \\
\hline Price paid by individual consumer during peak seasons of backyard chicken supplies \\
\hline$<5,000$ & 0 & $0 \%$ \\
\hline $5,000-10,000$ & 0 & $0 \%$ \\
\hline $11,000-15,000$ & 26 & $81.3 \%$ \\
\hline$>15,000$ & 6 & $18.7 \%$ \\
\hline Price paid by individual consumer during lean seasons of backyard chicken supplies \\
\hline$<5,000$ & 0 & $0.0 \%$ \\
\hline $5,000-10,000$ & 0 & $0.0 \%$ \\
\hline $11,000-15,000$ & 15 & $46.9 \%$ \\
\hline$>15,000$ & 17 & $53.1 \%$ \\
\hline Price an individual consumer is willing to pay for a mature backyard chicken \\
\hline$<5,000$ & 0 & $0.0 \%$ \\
\hline $5,000-10,000$ & 0 & $0.0 \%$ \\
\hline $11,000-15,000$ & 32 & $100.0 \%$ \\
\hline$>15,000$ & \multicolumn{2}{|c|}{$0.0 \%$} \\
\hline
\end{tabular}


Table.7 Individual consumers' preferences for chicken eggs $n=40$

\begin{tabular}{|l|c|c|}
\hline \multicolumn{1}{|c|}{ Variable } & Frequency & Percentage \\
\hline Kind of chicken eggs always bought by individual consumers \\
\hline Local & 10 & $25.0 \%$ \\
\hline Layers & 30 & $75.0 \%$ \\
\hline Hybrid & 0 & $0.0 \%$ \\
\hline Other & 0 & $0.0 \%$ \\
\hline Reason for buying the kind of chicken eggs by individual consumers \\
\hline Tasty & 4 & $10.0 \%$ \\
\hline Easily Available & 24 & $60.0 \%$ \\
\hline Cheap & 6 & $15.0 \%$ \\
\hline Healthy & 4 & $10.0 \%$ \\
\hline Other & 2 & $5.0 \%$ \\
\hline Most preferred Chicken eggs by individual consumers, keeping all other factors constant \\
\hline Local & 40 & $100.0 \%$ \\
\hline Layers & 0 & $0.0 \%$ \\
\hline Hybrid & 0 & $0.0 \%$ \\
\hline Price an individual consumer is willing to pay for a tray of the most preferred chicken eggs \\
\hline$<5,000$ & 0 & $0.0 \%$ \\
\hline $5,000-10,000$ & 0 & $0.0 \%$ \\
\hline $11,000-15,000$ & 40 & $100.0 \%$ \\
\hline$>15,000$ & 0 & $0.0 \%$ \\
\hline
\end{tabular}

Table. 8 Types of poultry included in restaurants' food menus $n=20$

\begin{tabular}{|l|c|c|c|c|c|c|c|c|}
\hline Rating & $\begin{array}{l}\text { Most } \\
\text { included } \\
(5)\end{array}$ & $\begin{array}{l}\text { More } \\
\text { included } \\
(4)\end{array}$ & $\begin{array}{l}\text { Included } \\
(3)\end{array}$ & $\begin{array}{l}\text { Least } \\
\text { included } \\
(2)\end{array}$ & $\begin{array}{l}\text { Not } \\
\text { included } \\
(1)\end{array}$ & $\begin{array}{l}\text { Cum. } \\
\text { score }\end{array}$ & Mean & $\begin{array}{l}\text { Overall } \\
\text { Ranking }\end{array}$ \\
\hline Response & 20 & 0 & 0 & 0 & 0 & 100 & 5 & $1^{\text {st }}$ \\
\hline Chicken & 0 & 0 & 0 & 0 & 20 & 20 & 1 & \\
\hline Turkeys & 0 & 0 & 0 & 0 & 20 & 20 & 1 & \\
\hline Pigeons & 0 & 0 & 0 & 0 & 20 & 20 & 1 & \\
\hline Ducks & 0 & 18 & 0 & 0 & 2 & 74 & 3.7 & $2^{\text {nd }}$ \\
\hline Chicken & & 0 & 0 & 0 & 20 & 20 & 1 & \\
\hline Eggs & 0 & 0 & & & & & & \\
\hline Others & & & & & & & & \\
\hline
\end{tabular}


Table.9 Types of chicken bought by restaurants $n=20$

\begin{tabular}{|l|l|l|l|l|l|l|l|l|l|}
\hline Answers & $\begin{array}{l}\text { Most } \\
\text { bought } \\
(6)\end{array}$ & $\begin{array}{l}\text { More } \\
\text { bought } \\
(5)\end{array}$ & $\begin{array}{l}\text { Bought } \\
(4)\end{array}$ & $\begin{array}{l}\text { Least } \\
\text { bought } \\
(3)\end{array}$ & $\begin{array}{l}\text { Rarely } \\
\text { bought } \\
(2)\end{array}$ & $\begin{array}{l}\text { Not } \\
\text { bought } \\
(1)\end{array}$ & $\begin{array}{l}\text { Cum. } \\
\text { Score }\end{array}$ & Mean & $\begin{array}{l}\text { Overall } \\
\text { Ranking }\end{array}$ \\
\hline Local & 16 & 3 & 0 & 0 & 0 & 1 & 112 & 5.6 & $1^{\text {st }}$ \\
\hline Exotic layers & 0 & 0 & 3 & 0 & 0 & 17 & 29 & 1.45 & $3^{\text {rd }}$ \\
\hline $\begin{array}{l}\text { Exotic } \\
\text { broilers }\end{array}$ & 4 & 6 & 0 & 0 & 0 & 10 & 64 & 3.2 & $2^{\text {nd }}$ \\
\hline Hybrids & 0 & 0 & 0 & 3 & 0 & 17 & 26 & 1.3 & $4^{\text {th }}$ \\
\hline Others & 0 & 0 & 0 & 0 & 0 & 20 & 20 & 1 & $5^{\text {th }}$ \\
\hline
\end{tabular}

Table.10 Reasons why restaurants bought the specific types of chicken $n=20$

\begin{tabular}{|l|l|l|l|l|l|l|l|l|}
\hline Answers & $\begin{array}{l}\text { Most } \\
\text { Important } \\
(5)\end{array}$ & $\begin{array}{l}\text { More } \\
\text { important } \\
(4)\end{array}$ & $\begin{array}{l}\text { Important } \\
(3)\end{array}$ & $\begin{array}{l}\text { Less } \\
\text { Important } \\
(2)\end{array}$ & $\begin{array}{l}\text { Not } \\
\text { Important } \\
(1)\end{array}$ & $\begin{array}{l}\text { Cumulative } \\
\text { Score }\end{array}$ & Mean & $\begin{array}{l}\text { Overall } \\
\text { Ranking }\end{array}$ \\
\hline $\begin{array}{l}\text { Customer } \\
\text { preference }\end{array}$ & 15 & 2 & 2 & 0 & 1 & 90 & 4.5 & $1^{\text {st }}$ \\
\hline $\begin{array}{l}\text { Easily } \\
\text { available }\end{array}$ & 1 & 13 & 1 & 0 & 5 & 65 & 3.25 & $2^{\text {nd }}$ \\
\hline Cheap & 0 & 3 & 2 & 0 & 15 & 33 & 1.65 & $4^{\text {th }}$ \\
\hline Healthy & 3 & 1 & 2 & 1 & 13 & 39 & 1.95 & $3^{\text {rd }}$ \\
\hline Others & 0 & 0 & 0 & 0 & 20 & 20 & 1 & $5^{\text {th }}$ \\
\hline
\end{tabular}

Table.11 Kind of chicken eggs most bought by restaurants $n=20$

\begin{tabular}{|l|c|c|}
\hline \multicolumn{1}{|c|}{ Kind of chicken Eggs } & Number of Restaurants & Percentage \\
\hline Indigenous/local & 3 & $15.0 \%$ \\
\hline Exotic layers & 17 & $85.0 \%$ \\
\hline Hybrids & 0 & $0.0 \%$ \\
\hline Others (any) & 0 & $0.0 \%$ \\
\hline Grand Total & 20 & $100.0 \%$ \\
\hline
\end{tabular}

Table.12 Kind of chicken eggs preferred by restaurant customers $n=20$

\begin{tabular}{|l|c|c|}
\hline \multicolumn{1}{|c|}{ Kind of chicken Eggs } & Number of Restaurants & Percentage \\
\hline Indigenous/local & 15 & $75.0 \%$ \\
\hline Exotic layers & 4 & $20.0 \%$ \\
\hline Exotic Broilers & 0 & $0.0 \%$ \\
\hline Hybrids & 0 & $0.0 \%$ \\
\hline Others (any) & 1 & $5.0 \%$ \\
\hline Grand Total & 20 & $100.0 \%$ \\
\hline
\end{tabular}


Table.13 Market Potential for poultry within Kumi District N=43,964 Households

\begin{tabular}{|l|c|c|c|c|}
\hline $\begin{array}{l}\text { Frequency } \\
\text { of } \\
\text { consumption }\end{array}$ & $\begin{array}{c}\text { Number of } \\
\text { Households }\end{array}$ & Percentage & $\begin{array}{c}\text { Estimated No. of } \\
\text { households from } \\
\text { Kumi district }\end{array}$ & $\begin{array}{c}\text { Annual consumption } \\
\text { from Kumi district }\end{array}$ \\
\hline Everyday & 4 & $10.0 \%$ & 4,396 & $1,604,540$ \\
\hline Once a Week & 23 & $57.5 \%$ & 25,280 & $1,314,560$ \\
\hline Fortnightly & 13 & $32.5 \%$ & 14,288 & 371,488 \\
\hline Once a month & 0 & $0 \%$ & 0 & 0 \\
\hline Occasionally & 0 & $0 \%$ & 0 & 0 \\
\hline Other & 0 & $0 \%$ & 0 & $3,290,588$ \\
\hline TOTAL & 40 & $100 \%$ & 43,964 & 0 \\
\hline
\end{tabular}

Table.14 Market Potential for poultry in the Districts of Kumi, Mbale and Soroti

\begin{tabular}{|l|c|c|c|c|}
\hline $\begin{array}{l}\text { Frequency of } \\
\text { of } \\
\text { consumption }\end{array}$ & $\begin{array}{c}\text { Number of } \\
\text { of } \\
\text { Households }\end{array}$ & Percentage & $\begin{array}{c}\text { Estimated Number of of } \\
\text { consuming households } \\
\text { from the 3 districts }\end{array}$ & $\begin{array}{c}\text { Annual consumption } \\
\text { from the 3 districts } \\
\text { (No. of birds) }\end{array}$ \\
\hline Everyday & 4 & $10.0 \%$ & 20,870 & $7,513,200$ \\
\hline Once a Week & 23 & $57.5 \%$ & 120,000 & $6,240,000$ \\
\hline Fortnightly & 13 & $32.5 \%$ & 67,826 & $1,763,476$ \\
\hline Once a month & 0 & $0 \%$ & 0 & 0 \\
\hline Occasionally & 0 & $0 \%$ & 0 & 0 \\
\hline Other & 0 & $0 \%$ & 0 & 0 \\
\hline TOTAL & 40 & $100 \%$ & 208,696 & $15,516,676$ \\
\hline
\end{tabular}

Fig.1 Business age of restaurants/hotels $n=40$

\section{Business Age of Restaurant/Hotel}

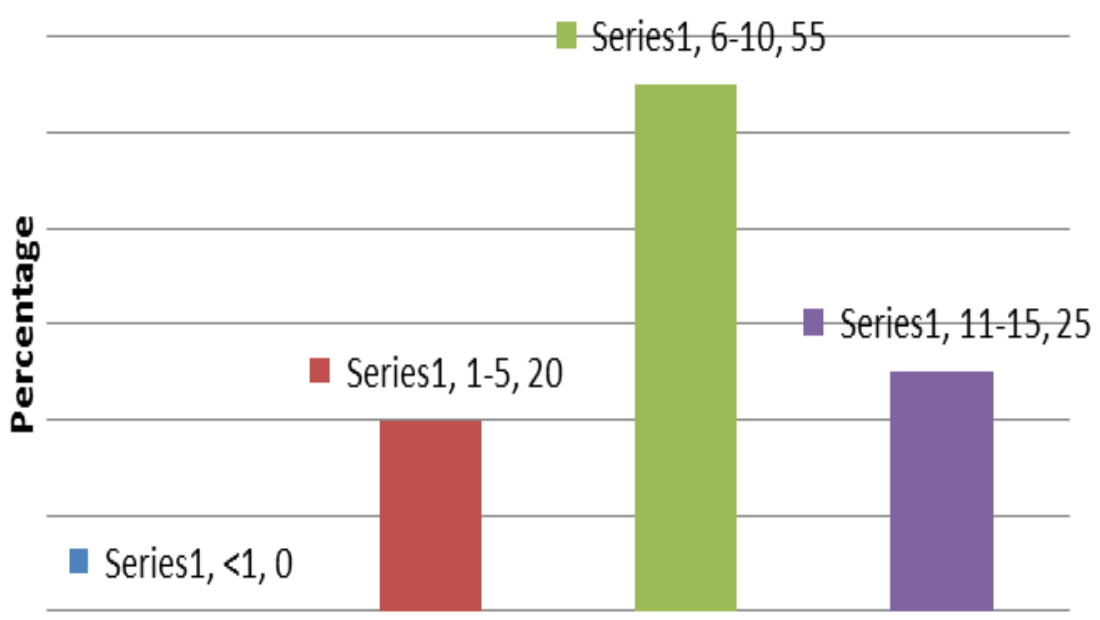




\section{Restaurants}

The prevailing poultry production system makes restaurants to depend on traders for their supplies. Some restaurants also buy directly from farmers. Most of the restaurants said they buy a local chicken at a range of UShs. 11,000 to 15,000 during both peak and lean seasons of supplies, while 6 restaurants bought at UShs. 11,000 to 15,000 during peak seasons and at above UShs. 15,000 during lean seasons. Layers and broilers were bought at UShs. 5,000 to 10,000 during both peak and lean seasons.

Types of poultry products included in restaurants' food menus

All the 20 restaurants surveyed included chicken in their daily food menus. 18 included chicken eggs in their daily food menus and 2 did not. None of the other poultry products were included in their food menus (Table 8).

Table 8 shows that chicken and chicken eggs were ranked as the only and top two poultry products included in menus of restaurants.

\section{Type of chickens bought by restaurants}

Table 9 indicates that 16 restaurants said their first priority chicken type for their customers was local chickens; 4 said their first priority was broilers.

17 restaurants bought neither Kuroiler nor layer chickens; 10 never bought broilers and 1 never bought local chicken.

As indicated in Table 9, overall, the indigenous chicken was ranked as first priority chicken bought by the restaurants, followed by exotic broilers, exotic layers, hybrids and others (like cross breeds) in that order.
The first priority reason for choosing the types of chicken bought by restaurants was customer preference (Table 10). Other priorities included availability ( $2^{\text {nd }}$ priority), health issues $\left(3^{\text {rd }}\right.$ priority) and cost $\left(4^{\text {th }}\right.$ priority). Just as indicated by the traders, the restaurants also said that their customers considered the local chickens to be healthier than the exotic as limited chemicals are administered to them by farmers. Broilers are preferred by a few customers, especially foreigners, because they are soft. All surveyed restaurants expressed interest in engaging reliable suppliers of backyard chickens, and they all preferred chicken carcass weight of 1.6 to 2.0Kgs. Although Katule (1998) observed that variation exists between indigenous chicken ecotypes for adult body weight, research has indicated that most backyard chickens are usually of the range 1 to $2.0 \mathrm{kgs}$ in terms of body/carcass weight (Sorensen and Ssewanyana, 2003). Therefore, all the restaurants' and $75 \%$ of individual consumers` preferences fall within this range, hence proving a potential for commercialisation of the backyard chickens.

Kind of chicken eggs bought by restaurants and chicken eggs preferred by restaurant customers

Despite the greater preference for indigenous/local chicken eggs to other kinds of eggs by restaurant customers (Table 12), only 3 of the surveyed restaurants actually bought the indigenous/local chicken eggs (Table 11). This is because local chicken eggs are rare to get, and are expensive. This offers an opportunity for a wide scale (commercialized) production of indigenous chicken eggs to bridge the unmet need.

\section{Market potential for poultry in the region}

Kumi district has 43,964 households, with an average of 6 household members each, 
(UBOS, 2014). Taking each individual sampled to represent a household, the annual market potential due from these households for poultry is computed in Table 13 to be $3,290,588$ birds per year. This implies that Kumi district can contribute in producing this number of birds to meet the demand. Further analysis revealed that the $20 \%$ of the individual consumers, who preferred broilers (Table 4), all preferred eating them fortnightly, thus the potential for broilers is 658,118 broilers per year and the rest is for backyard poultry, i.e. 2,632,470 birds. If $10 \%$ of households in Kumi district keep and multiply 50 backyard chickens per year they will be able to produce 4,396,400 backyard birds which would meet the demand of the individual consumers $(2,632,470$ birds $)$ within Kumi district alone, with the excess production taken by restaurants/hotels and other customers, but would not meet the demand for an aggregated market of Kumi, Mbale and Soroti districts (Table 14).

The individual consumers were sampled from districts of Mbale, Soroti and Kumi, having 109,537, 55,195 and 43,964 households respectively, with an average of 5 household members each, (UBOS, 2014). This gives a total of 208,696 households.

Taking each individual to represent a household, the annual market potential due from these households for the backyard poultry is computed in Table 14 to be $15,516,676$ birds per year. This implies that Kumi district can contribute in producing this number of birds to meet the demand. Further analysis revealed that the $20 \%$ of the individual consumers, who preferred broilers (Table 4), all preferred eating them fortnightly, thus the potential for broilers is $1,085,220$ broilers per year and the rest is for backyard poultry, i.e. 14,431,456 birds. This implies a huge potential for commercialisation of backyard poultry in
Kumi district.

\section{Marketability of backyard chicken and their eggs}

According to the respondents, market for both backyard chicken and their eggs was available, and indigenous chicken eggs fetched more money than the exotics. There was an unmet demand for these products, and Kumi district was known all over Uganda as one of the major sources of backyard chickens. All the restaurants and traders expressed their interest in dealing with reliable suppliers of indigenous chickens and eggs. All the restaurants and individual consumers indicated that they would be willing to buy local chickens at a price from UShs. 11,000 to 15,000 . Restaurants also offered to buy other breeds, if need be, at prices lower than this range.16 restaurants indicated willingness to pay UShs 11,000 to 15,000 for a tray of local chicken eggs, and UShs. 5,000 to 10,000 for a tray of either layer or hybrid chicken eggs.

Out of this study, individual consumers preference for backyard chickens and their eggs was noted, and this shaped the preference for the same by poultry traders and restaurants/hotels. The backyard poultry (chickens) and their eggs were considered as being better in terms of high demand, taste and health, thus taken as a better option for commercialisation as human population keeps growing. Moreover, while poultry traders offered UShs. 7,000 to 11,000 to the farmers for each backyard chicken, both individual consumers and restaurants/hotels were willing to offer UShs. 11,000 to 15,000 to the farmers, and the same offer for a tray of indigenous chicken eggs. A market potential of 2,632,470 backyard poultry birds per annum was computed for Kumi district alone and 14,431,456 birds for a combination of Kumi, Mbale and Soroti districts. This study therefore proved that the good taste of 
backyard chickens that is appealing to majority consumers, the high frequency desired by the consumers to eat chicken, coupled with the preferred body weight of the chickens which rhymes with that of local chickens, offered an opportunity to commercialise production of backyard chickens.

\section{References}

Katule, A.M., 1998. Study on the productivity of indigenous chickens under village management conditions. In proceedings of the $25^{\text {th }}$ Scientific Conference AICCArusha, August 5-7, 1998 pp. 48-54.

Kryger, K.N., Thomsen, K.A., Whyte, M. A. and Dissing M., 2010. Smallholder Poultry Production - Livelihoods, Food Security and Sociocultural Significance, FAO Smallholder Poultry Production Paper No.4.Rome.retrieved from http://www.fao.org/docrep/013/al674e/al67 4e00.pdf

MAAIF \& UBOS, 2009. Ministry of
Agriculture Animal Industry and Fisheries (MAAIF) and Uganda Bureau of Statistics (UBOS). Livestock Census Report. MAAIF and UBOS Kampala, Uganda.

Olaboro, G., 1990. Smallholder Rural Poultry Production in Uganda. Country Report pp-35

Sorensen, P., and Sewanyana E., 2003. Progress of the SAARI chicken breeding project- Analysis of growth capacity In: Proceedings of the LSRP Annual Scientific Workshop, March 2003, Kampala

Uganda Bureau of Statistics, 2013. Statistical Abstracts

Uganda Bureau of Statistics, 2014. National Population and Housing Census 2014 Provisional Results. November 2014. Revised Edition. Retrieved from http://unstats.un.org/unsd/demographic/ sources/census/2010_PHC/Uganda/UG A-2014-11.pdf

\section{How to cite this article:}

Iisa Augustine and Ruchira Shukla. 2017. A Study of Consumer Preferences and Market Potential for Poultry Products in Kumi District of Uganda. Int.J.Curr.Microbiol.App.Sci. 6(10): 2800-2813. doi: https://doi.org/10.20546/ijcmas.2017.610.328 